\title{
FINANCIAL RESOURCES AND JUNIOR SECONDARY SCHOOL STUDENTS' ACADEMIC PERFORMANCE IN CROSS RIVER STATE, NIGERIA
}

\section{OFEM, WOKASOR ENI, AKEKE, MERCY NKIRUKA GODWIN AND AMEH, EYIENE}

(Received 10 May 2021 Revision Accepted 17, August 2021)

\begin{abstract}
The study investigated the relationship between financial resources and junior secondary school students' academic performance in Cross River State, Nigeria. Four null hypotheses were formulated and tested. Ex-post facto design was used for the study. Subjects who participated in the study were 397 students from 277 public junior secondary schools in the study area but data was collected from only 386 representing 97.2 percent. Two instruments titled "Financial Resources Questionnaire (FRQ) and Junior Secondary School Students' Academic Performance Scale (JSSSAPS)" were used for data collection. Data was analyzed using Population t-test and Multiple Regression analysis. The result indicated that junior secondary school students' academic performance is significantly high. The result further revealed that financial resources in terms of: investment in school facilities, allocation of financial resources, structure of financial resources and amount of financial resources jointly predicts students' academic performance. It was concluded that school business just like every other economic unit and business concerns alike, cannot thrive by mere availability of financial resources but by its utilization.
\end{abstract}

KEYWORDS: Financial resources, Allocation, Investment, school facilities, Students' academic performance.

\section{INTRODUCTION}

Finance is concerned with the determination of economic value, acquisition, allocation, utilization and investment of resources to achieve the objectives of different economic units such as government, business firms, organizations and households (Campell, 2004 and Boma, 2018). Public school financial resources usually include funds from sources such as tuition, Parent
Teachers' Association (PTA) levy, trust fund, development levy, government subventions, donations, education investments in marketable securities, et cetera. Education finance therefore refers to government and/or organization processes by which revenues are generated through taxation, tuition fees and philanthropy, distributed and expended for the operation and capital support of formal schooling (Guthrice \& Schuerman, 2017; Tyger, 2018). School financial

Ofem, Wokasor Eni, Department of Educational Management, University of Calabar,

P.M.B 1115 Cross River State, Nigeria

Akeke, Mercy Nkiruka Godwin, Department of Vocational Education, University of Calabar, P.M.B 1115 Cross River State, Nigeria

Ameh, Eyiene, Department of Educational Management, University of Calabar, P.M.B 1115, Cross River State, Nigeria

(C) 2021 Bachudo Science Co. Ltd. This work is Licensed Under Creative Commons Attribution 4.0 international license. 
resources is used for building office accommodation and classrooms, training of teachers, payment of salaries and wages, provision of instructional materials and recreational facilities and investment for future consumption opportunities, among others.

Financial resources are of fundamental importance in the management of education at all levels globally. It is an essential educational resource which determines the quality and quantity of other resources needed for the proper functioning of the education sector (Irikana \& Weli, 2019). Therefore, no educational system can thrive without financial resources. The development of every educational system and the attainment of educational goals is tied to the availability of financial resources. Thus, finance is an indispensable tool in processing educational products for quality output.

School financial resources refer to all physical and monetary resources within the parameters of the school system meant for exploitation and allocation for production function. Financial resource according to Oyekan, Adelodun and Oresajo (2015), is the monetary resource which serves as a means of acquiring all other educational resources. Its availability and mobilization is of great importance to any education industry.

Hedges, Pigott, Polanin, Ryran, Tocci and William (2016) argued that one of the issues of contention in education financial research is how and whether the resources provided to schools relate to students' academic achievement. In other words, does money matter to students' academic performance? Increasing school financial resources can contribute to such factors such as teacher quality, administrative capacity, students' resources and facility investment which all have the potential to greatly affect student's achievement. But the structure of school finance may also play a part in increasing academic performance. For instance, a finance system that fails to provide adequate teacher salaries may result in reduced teacher quality, as more experienced educators may leave relatively low paying jobs for better prospects with higher reward. On the other hand, a system that provides overly generous salaries and benefits for teachers may fail to invest in facilities such as classrooms, auditoriums or computer labs which may put students at a disadvantaged position and stifle learning opportunities. Though the amount of resources spent on education matters, the ways in which finance systems allocate these resources also play an important role in promoting or impeding academic performance (Andrew, 2016; Hedges et al 2016).

Consequently, academic performance has been of serious concern among stakeholders as students' educational outcome declines. Osim, Akeke and Uchendu (2015) observed that poor work performance by teachers in Cross River State is as a result of inadequate educational support variables such as school facilities. Adequacy of school facilities provides conducive working environment for teachers with its ripple positive effect on students' outcome in secondary educational level.

Academic performance according to Nnamani, Dikko, and Kinta (2014) is defined or regarded as participants' examination grades at the end of a given duration (term, semester, programme). Ebenuwa cited in Nnamani et al (2014) avered that students' academic performance affects the quality of human resources within the society. It is particularly true, because the manpower population of a country is a product of graduate output of various levels and types of educational institutions. It therefore suggest that secondary school leavers output with low academic performance will bequeath to the society human resources without competence and capacity to drive the economy. However, this has become a major problem that requires urgent and serious solution.

\section{LITERATURE REVIEW}

Carmel, Ulrich, Meg and Baffour (2018) provided evidence of quarterly approach to school funding in the United States of America. The study drew lessons from school finance litigations. Using survey design and questionnaire instrument, the study revealed that the types of curriculum, quality of teachers, and the effectiveness of administrators significantly influence academic outcomes. The amount of money spent on students and the mechanism that finance public education system also has a strong effect on academic success. The authors also found that increased funding contributes to teachers' quality, administrative capacity, and student resources and facility investments. Additionally, the study indicated that the school structure of finance in terms of remuneration of teachers, influences student academic performance. The amount of financial resources allocated, utilized and invested in school facilities enhances learning opportunities with attendant effect on academic achievement.

Hedges, Pigott, Polanin, Ryran, Tocci and Williams (2016), in an empirical study attempted 
to provide answers to the question of school resources and student achievement from a historical perspective. Predictive models were employed to measure academic achievement including a measure of per-pupil expenditure and control for race and either socio-economic status or prior achievement with a meta-analysis conducted separately for previous studies at the level of district and at the level of student. The major finding was a non-statistical relationship between per-pupil expenditure and academic achievement based on a small set of studies both at the district and student levels.

Nwite cited in Tyger (2018) found that financial resources allocation to secondary schools significantly influence students' performance. The author also noted positive relationship between human resource allocation and students' performance. Even though education in Nigeria is in the concurrent legislative list of the Constitution; it is not part of the priority focus of the current democratic regime of President Muhammadu Buhari. This accounts for why there is continuous decline of budgetary allocation to it. The 2020 economic recession further exacerbated financial constraint across sectors of the economy. This is consistent with Omolade (2007) and Hinchcliffe (2002), that financial constraints in the country have made education to suffer setback. Again the poor funding of postbasic education is based on inconsistent educational policy and educational goals as it suits the current federal political dispensation whose priority focus is; the economy, fighting corruption, and insecurity. Nicolleti and Rabe cited in Tyger (2018), found that in the United Kingdom, school level spending on educational support staff and learning resources helps close the achievement gap between advantaged and disadvantage students.

Wanjala, Wamocha and Sang (2020) investigated the relationship between principals' financial management practices and students' academic achievement in public secondary schools in Bungoma East Sub-County. Embedded mixed method research design was adopted for the study. The target population was all principals, deputy principals and heads of department in public secondary schools in the Sub-County. Stratified random sampling was used to select the study sample. In total, 180 respondents, comprising of 33 principals, 33 deputy principals and 114 heads of department, were picked from 33 sampled schools. Data was collected using questionnaire, interview schedule and document analysis guide. A pilot study was carried out in three schools from the neighbouring Sub-County before the main study to establish validity and reliability of the research tools. Both descriptive and inferential statistics were used in data analysis. Descriptive statistics involved the use of frequencies, percentages and means while inferential statistics involved the use of Spearman's Rank order correlation. The study established a strong positive relationship between principals' financial management practices and academic achievement in public secondary schools. Therefore, principals who had high scores on financial management practices recorded high academic mean scores in their schools. Financial managerial practices play a pivotal role in infrastructural and academic development of an educational institution. It was thus recommended that school principals should ensure that school financial resources were properly managed to ensure there was proper development of schools' infrastructures hence improvement of academic performance.

Nwite (2016) examined financial allocation to education and students' performance in Nigeria. Two research questions and two hypotheses involving financing secondary education and students' performance in Senior Secondary School Certificate Examination guided the study. The population comprised all public secondary schools in South-East and South-South geopolitical zones of Nigeria. The proportionate stratified random sampling technique was used to select a sample of 1000 schools in agreement with the number of secondary schools in each of the two geo-political zones. The instrument was a checklist tagged "Federal Government Resource Allocation to Secondary Education 1988-2007". Inferential statistics of Pearson Product Moment Correlation Coefficient ( $r$ ) was employed to test the hypotheses at 0.05 alpha level. The result showed significant relationship between financial allocation and students' performance. Adequate financial resource allocations to secondary schools significantly influence students' performance. Significantly, the study would be of immense value to Ministry of Education, principals, parents and stakeholders as the findings would provide information on the efficacy and benefits of adequate funding of secondary school. Inadequate funding of education impacted negatively in each state of the federation as many of the schools lacked qualified teachers and facilities plus abandoned school projects dilapidated school plants and poor school environment. 
Increasing empirical evidence indicates that increased spending on education lead to better students' academic performance. Where the state invest in her public schools and create more equitable school finance systems, student achievement levels rise, and the positive effects are even greater among low-income students (Carmel et al 2018). Baker cited in Oyekan et al (2015), stated that an average, aggregate measure of per pupil spending is positively associated with improved or higher students' learning outcomes. In some studies, the size of this effect is larger than in others and, in some cases, additional funding appears to matter more for some students than others. According to the authors, there are other factors that may moderate the influence of funding on students' learning outcomes, such as how that money is spent. In other words, there must be prudence in the expenditure of financial resources to yield benefits.

Tyger (2018) analyzed the effect of functionalized allocation on students' performance in Rivers State, Nigeria. The study employed ex-post facto design with data extracted from government gazettes of budgetary allocations. Result showed a significant effect of financial resources on students' academic performance. Therefore, the higher the budgetary provision to education, the higher the student academic performance. Similarly, Jackson, Johnson and Persico (2014) reported that low-income children in districts that implemented school finance reform completed more years of education, earned higher incomes and were less likely to experience poverty than poor children in district that did not implement reform that increased funding. These authors employed Ordinary Least Square regression analysis. In as much as the literatures reviewed are relevant, this present study filled some existing gaps in terms of the variables (amount of school financial resources, allocation of school financial resources, amount of investment and structure of school financial resources), study area, sampling size determination and instrumentation.

\section{STATEMENT OF THE PROBLEM}

The place of financial resources in the day-to-day administration of schools cannot be over emphasized. It is the fulcrum upon which the procurement of related inputs for production function in the educational system is predicated. Ideally, the amount of this very important resource, its allocation, investment orientation and structure, all things being equal, is supposed to positively affect students' learning outcomes in a given school system. But in recent time, the academic performance of junior secondary school students in Cross River State is fraught with low grades in their termly and sessional examination results. Some of them exhibit apathy toward related academic activities culminating into decline in performance. This unfortunate situation is not tenable considering the fact that the importance of financial resources has been well extolled in the literature of this study.

The question of whether financial resources directly translate into academic achievement gains has not been adequately addressed in empirical studies. Therefore, it may be impossible to explore the complexity of schools and the critical role of students' background and academic performance. Interestingly, there is a need to/for research on how financial resources can be deployed to support students' academic performance in a socio-economically diverse and multi-cultural society like Cross River State. From the aforesaid, the poser that this present study seeks to provide answer to is: Does amount of financial resources, allocation of financial resources, amount of investment in school facilities, and structure of school financial resources relate with students' academic performance?

\section{STATEMENT OF HYPOTHESES}

The following null hypotheses were formulated and tested:

1. Junior secondary school students' academic performance in Cross River State is not significantly high.

2. Amount of school financial resources, allocation of school financial resources, amount of investment in school facilities and structure of school financial resources has no significant influence on junior secondary students' academic performance.

\section{METHODOLOGY}

The study adopted ex-post facto design. The research area was Cross River State, comprised of 18 local government areas with a total of 277 public junior secondary schools. The population stood at 57,920 junior secondary school (JSS II) students. Using the Taro Yamane's sample size calculation formula, 397 were selected to form sample of the study. At the end of administration of questionnaire exercise, 97.2 percent response and 2.8 percent attrition rates were recorded. Out of 397 copies of the instrument administered, 386 were collected and 11 were not found. 
Data was collected with the aid of two instruments titled: "Financial Resources Questionnaire (FRQ) and Junior Secondary School Students' Academic Performance Scale (JSSSAPS)". FRQ was based on a 4-point modified Likert Scale which comprised of sixteen (16) items designed to measure school financial resources in terms of: amount of financial resources, allocation of financial resources, investment in school facilities, and structure of school finance. Each variable was measured using four (4) items and each item had four options ranging from Strongly Agree (SA), Agree (A) to Disagree (D) and Strongly Disagree (SD). JSSSAPS dealt with the dependent variable of academic performance and comprised of ten (10) multiple choice items in social studies with one correct answer. The research instrument was subjected to face validity by two experts in Measurement and Evaluation who ensured that ambiguous statements were corrected. Data collected was analyzed using IBM SPSS version 26.0, which consisted of population t-test and multiple regression analysis.

\section{RESULTS Hypothesis one}

Junior secondary school students' academic performance in Cross River State is not significantly high. The result of the test of this hypothesis is as presented in table 1 .

Table 1

Summary of population t-test result of junior secondary school students' academic performance in Cross River State. $\mathrm{N}=386$.

\begin{tabular}{llllll}
\hline Variable & Sample mean & $\mu$ & SD & SE & t-cal \\
\hline $\begin{array}{l}\text { Students' } \\
\begin{array}{l}\text { academic } \\
\text { performance }\end{array}\end{array}$ & 13.91 & 15 & 1.43 & 0.73 & $14.85^{*}$ \\
\hline
\end{tabular}

${ }^{*}$ Significant at $.05, \mathrm{df}=385$, critical $r$-value $=1.966, \mu=$ hypothesized population mean

The results presented in Table 1 , revealed that the calculated t-value of 14.85 is greater than the critical value of 1.966 meaning that, $p<.05$ at 385 degrees of freedom. With this result, the null hypothesis is rejected implying that, secondary school students' academic performance in Cross River State is significantly high.

\section{HYPOTHESIS TWO}

Amount of school financial resources, allocation of school financial resources, amount of investment in school facilities and structure of school financial resources has no significant influence on junior secondary school students' academic performance. The result of the test of this hypothesis using multiple regression analysis is as presented in table 2 .

\section{TABLE 2}

Summary of multiple regression on the influence of amount of school financial resources, allocation of school financial resources, amount of investment in school facilities and structure of school financial resources on junior secondary students' academic performance. $\mathrm{N}=386$.

\begin{tabular}{llll}
\hline Multiple R & R square & Adjusted R square & SE \\
\hline 0.221 & 0.049 & 0.039 & 1.416
\end{tabular}

The result as presented in table 2 revealed that; amount of financial resources, allocation of financial resources, investment in school facilities, and structure of school finance, have a positive multiple correlation with junior secondary school students' academic performance $(R=$ .221). This implies that the variables (amount of financial resources, allocation of financial resources, investment in school facilities, and structure of school finance) to an extent, are quite relevant towards the determination of junior secondary school students' academic performance. These variables explained $49 \%$ of the total variance of junior secondary school students' academic performance in Cross River State ( $\mathrm{R}$ Square $=.049$ ). By practical implication, the remaining $51 \%$ of the total variance, may have been due to other factors not studied presently. In determining whether the R Square value of .049 obtained was statistically significant 
or not, the analysis of variance (ANOVA) of the

Table

3

below. regression analysis was presented as shown in

Table 3

Analysis of variance (ANOVA) of the Regression Analysis

\begin{tabular}{llllll}
\hline Source of variation & Df & SS & MS & F & Sig F \\
\hline Regression & 4 & 38.678 & 9.670 & & \\
Residual & 380 & 751.493 & 1.978 & 4.890 & .001 \\
Total & 384 & 790.171 & & & \\
\hline
\end{tabular}

${ }^{*}$ Significant at $p<.05$

The results presented in Table 3 shows clearly that, the p-value .001 obtained is less than .05 level of significance (i.e. $F=4.890 ; p=.001<$ .05). With this result, the null hypothesis is rejected implying that, amount of financial resources, allocation of financial resources, investment in school facilities, and structure of school finance has significant influence on junior secondary school students' academic performance. Hence, the R Square value of .049 obtained, was not due to chance. In order to determine the variable with the highest influence on junior secondary school students' academic performance, the relative contributions of the four variables (amount of financial resources, allocation of financial resources, investment in school facilities, and structure of school finance) to junior secondary school students' academic performance was used as presented in Table 4.

Table 4

Relative contributions of financial resources on junior secondary school students' academic performance

\begin{tabular}{llllll}
\hline Variables & Coefficient & SE & t-stat & Sig & Rank \\
\hline Constant & 10.217 & 1.333 & 7.665 & .000 & \\
Investment & .234 & .055 & 4.292 & .005 & $1^{\text {st }}$ \\
Allocation & .049 & .051 & 1.960 & .040 & $2^{\text {nd }}$ \\
Amount & .009 & .051 & 1.180 & .008 & $4^{\text {th }}$ \\
Structure & .027 & .051 & 1.539 & .001 & $3^{\text {rd }}$ \\
\hline
\end{tabular}

The results presented in table 4 revealed that, the four variables were statistically significant in influencing junior secondary school students' academic performance in Cross River State. This is because their $p$-values were all less than the alpha level respectively. (i.e. p-values $.005, .040$, .008 and .001 are all $<.05)$. Out of the four variables studied, investment in school facilities had the highest influence $(t=4.292)$; followed by allocation of financial resources $(t=1.960)$; then structure of financial resources $(t=1.539)$ and lastly amount of financial resources $(t=1.180)$ on junior secondary school students' academic performance.

\section{DISCUSSION}

The result of hypothesis one testing as presented in Table 1 revealed that junior secondary school students' academic performance in Cross River State is significantly high. This result does not imply that the performance of junior secondary school students in the state was near perfection, it simply revealed that their academic performance was above average. Findings from result of this hypothesis testing conform with Carmel, Ulrich, Meg and Baffour (2018) conclusion that the amount of financial resources allocated, utilized and invested in school facilities enhance learning opportunities with attendant effect on academic achievement. Contrary wise, finding from hypothesis one testing disagree with Carmel et al (2018) whose study found that the amount of money spent on students and the mechanism that finance public education system adopt, have a strong effect on academic success. The results of hypothesis two revealed that the four variables which includes investment in school facilities, allocation of financial resources, amount of financial resources and structure of financial resources had a combined positive relationship that was statistically significant in predicting junior secondary school students' academic performance. When these four variables are jointly managed together, they 
influenced junior secondary school students' academic performance. However, out of the four variables, investment in school facilities had the highest influence followed by allocation of financial resources, then structure of financial resources and amount of financial resources in that order on junior secondary school students' academic performance in Cross River State.

This finding is an indication that adequately funded schools enhances students' academic performance. This finding corroborate the findings of Hedges et al (2016), whose empirical study attempted to provide answers to the question of school resources and student achievement from a historical perspective. Their major finding was a non-statistical relationship between per-pupil expenditure and academic achievement based on a small set of studies both at the district and student levels respectively.

This finding is an indication that the quantum of allocation of school financial resources to postbasic education in the area of study, students' academic performance may improve. This finding is in agreement with the findings of Nwite cited in Tyger (2018) whose empirical study found that financial resources allocation to secondary schools significantly influence student performance. The author also noted positive relationship between human resource allocation and student performance.

This finding acquiesce to that of Carmel et al (2018) who averred in their study that where state invest in their public schools and create more equitable school finance systems, student achievement levels will rise, and the positive effects are even greater among low-income students. Further finding from their study show that increased funding contributes to teachers' quality, administrative capacity, and student resources and facility investments. Adequacy and quality of school facilities provides conducive environment for teaching and learning experience. Consequently, schools with standard and globally competitive indoor and outdoor facilities will enhance students' academic performance within the study area and beyond. Again, this finding is agreement with Carmel et al (2018) study, whose finding indicated that the school structure of finance in terms of remuneration of teachers influences student academic performance. The amount of financial resources allocated, utilized and invested in school facilities enhances learning opportunities with attendant effect on academic achievement.

\section{CONCLUSION}

Schools just like every other economic unit and business concerns alike cannot thrive by mere availability of financial resources but by its utilization. Nevertheless, findings from this study indicates that school financial resources in terms of; investment in school facilities, structure of financial resources, amount of financial resources and allocation of financial resources, does significantly relate with junior secondary school students' academic performance in Cross River State. Furthermore, a student whose performance is high is not a function of the quantum of allocation their school received but other variables not studied.

\section{RECOMMENDATIONS}

1. Financial resources remains the nucleus upon which all inputs in the production process in the school system revolve. Therefore, the provision and prudent utilization of financial resources should not be reneged.

2. Educational managers should leverage pedagogical strategies which enhances students' academic performance.

3. Post-basic education policy framework should be tailored to the provision of basic instructional and physical facilities like public power supply for utilization by students regardless of parents' socioeconomic status.

\section{REFERENCES}

Andrew, E. C. 2016. School finance decisions and academic performance: An analysis of the impacts of school expenditures on student performance, (Department of Public Policy and Administration, California State University, Sacramento)

Boma, B. P. 2018. Financial management and practices for principals for quality service delivery in secondary schools in Rivers State. International Journal of Innovative Finance and Economics Research, 6 (2), 62-69.

Campbell, R. F. 2004. Introduction of education administration. London: Allyn and Bacon Inc. 
Carmel, M., Ulrich, B., Meg, B. and Baffour, P. 2018. A quarterly approach to school funding: Lessons learned from school finance litigation. Centre for America Process.

Guthrice, J. W. and Schuerma, P. J. 2017. Oxford bibliographies. Education Finance - Education - Oxford bibliographies. www.oxfordbibliographics.com

Hedges, L., Pigott, T., Polanin, J., Ryran, A., Tocci, C. and Williams, R. 2016. The question of school resources and student achievement: A history and reconsideration. Review of Research in Education Centennial Edition, 40, 143168.

Hinchcliffe, K. 2002. Public expenditure on education in Nigeria: Issues, estimates and some implications. Abuja: World Bank.

Irikana, D. G. and Weli, S. E. 2019. Analysis of constraints and strategies in funding educational sector for academic performance in secondary schools in Rivers State. International Journal for Innovative Education Research, 1-12.

Jackson, C. K., Johnson, R., and Persico, C. 2014. The effect of school finance reforms on the distribution of spending, academic achievement and adult outcomes. NBER Working Paper No. 20118.

Cambridge, MA: National Bureau of Economic Research.

http://www.Nber.org/papers/w20118.

Osim, R. O; Akeke, M. N. G. and Uchendu, C. C. 2015. Educational support variables and teachers' work performance in secondary schools in Cross Rivers State, Nigeria. Nigerian Journal of Educational Administration and Planning. 15 (3), 733744.

Nnamani, C. N., Dikko, H. G. and Kinta, L. M. 2014. Impact of students' financial strenght on their academic performance: Kaduna Polytecnic experience. International Multidisciplinary Journal, Ethiopia, Vol. 8 (1). , 83-98.

Nwite, O. 2016. Financial allocation to secondary education in Nigeria: Implication for students performance. Journal of Research \& Method in Education, 6(3), 42-47. DOI: 10.9790/7388-0603014247

Omolade, O. A. 2007. Financing higher education in Nigeria. International Journal of African and American Studies, 1 (1), 69-75.

Oyekan, O. A., Adelodun, S. S. and Oresajo, N. O. 2015. Allocation of financial resources to enhance educational productivity and students' outcomes in Nigeria. International Journal of Development and Management Review (INJOEMAR) Vol. 10 June., 201-209.

Tyger, M. S. 2018. Financial resources allocation and its implication for students' performance in Rivers State, Nigeria. International Journal of Innovative Finance and Economic Research, 6 (3), 27-33.

Wanjala, J., Wamocha, L. and Sang, A. 2020. Effect of principals' financial management practices on academic achievement in public secondary schools in Bungoma East Sub-County, Kenya. British Journal of Education, 8(9), 13-27. 